\title{
Penentuan Leading Sector Industri dalam Akselerasi Pariwisata untuk Menumbuhkembangkan Ekonomi Kabupaten Banyuwangi
}

\author{
${ }^{1 *}$ Jemi Cahya Adi Wijaya, ${ }^{2}$ Rudi Tri Handoko \\ ${ }^{1,2}$ Politeknik Negeri Banyuwangi \\ *jemi.cahya@poliwangi.ac.id
}

\begin{abstract}
Tourism is one of the economic roots in Banyuwangi Regency which provides a trend with positive and significant values. The harmonization of the tourism sector with the creative economy sectors, such as industries and innovation carried out by the government in a sustainable manner are expected to be an alternative in the development of the regional economy through a multiplier effect. This study aims to identify the leading and non leading sectors of the business and industrial fields, so it can accelerate the tourism sector in Banyuwangi Regency. The analytical tools used are location quotient and shift share analysis. The results show that agriculture, forestry and fisheries, mining and excavation, the construction, and the education service as the leading sectors can be collaborated for accelerating tourism in Banyuwangi Regency. The performance of them can be proven from the results of the shift share analysis with a value that tends to be positive towards accelerating tourism in Banyuwangi Regency.
\end{abstract}

Keywords : tourism, Location Quotient (LQ), shift share, leading sector

\begin{abstract}
Abstrak
Pariwisata merupakan salah satu akar perekonomian di Kabupaten Banyuwangi yang memberikan tren dengan nilai positif dan signifikan. Harmonisasi bidang pariwisata dengan para pelaku ekonomi kreatif, industri, dan inovasi yang dilakukan oleh pemerintah secara berkelanjutan diharapkan dapat menjadi suatu alternatif dalam pengembangan perekonomian daerah melalui suatu multiplier effect. Penelitian ini bertujuan untuk mengidentifikasi sektor-sektor basis dan non basis lapangan usaha/industri sehingga dapat mengakselerasi sektor pariwisata di Kabupaten Banyuwangi. Alat analisis yang digunakan yaitu analisis location quotient dan analisis shift share Hasil penelitian menunjukkan bahwa terdapat beberapa sektor lapangan usaha/industri yang menjadi sektor basis untuk dapat dikolaborasikan dalam mengakselerasi sektor pariwisata di Kabupaten Banyuwangi, diantaranya sektor pertanian,kehutanan dan perikanan, sektor pertambangan dan penggalian, sektor konstruksi, dan sektor jasa pendidikan. Kinerja masing-masing sektor basis dari lapangan usaha/industri tersebut dapat dibuktikan dari hasil analisis shift share dengan nilai yang cenderung positifterhadap akselerasi pariwisata di Kabupaten Banyuwangi.
\end{abstract}

Kata kunci : pariwisata, Location Quotient (LQ), shift share, leading sector

\section{Pendahuluan}

Pariwisata merupakan akar perekonomian di Kabupaten Banyuwangi yang memberikan tren dengan nilai positif dan signifikan. Menurut data dari Badan Pusat Statistik (BPS) Banyuwangi dalam Angka tahun 2019 laju pertumbuhan tertinggi berturut-turut diisi oleh sektor konstruksi, perdagangan dan ecaran, penyediaan akomodasi dan makanan,jasa lainnya serta sektor informasi dan komunikasi,dimana kelima sektor tersebut merupakan sektor yang berhubungan terhadap perkembangan ekonomi pariwisata Kabupaten Banyuwangi.

Harmonisasi antara bidang pariwisata dengan para pelaku ekonomi kreatif, industri, dan inovasi yang dilakukan oleh pemerintah secara berkelanjutan menjadi suatu alternatif dalam pengembangan perekonomian daerah melalui suatu multiplier effect. Dampak berganda ini yang kemudian menarik sektor lain untuk ikut berkembang. Menurut Rustiadi (2011) menyatakan bahwa 
suatu daerah akan mengalami percepatan pertumbuhan apabila memiliki sektor ekonomi yang mampu mengakselerasi pembangunan serta sektor-sektor yang lain.

Pertumbuhan ekonomi menjadi sebuah tantangan yang besar saat ini terlebih ketika dihadapkan dengan situasi dan kondisi berupa ancaman perlambatan ekonomi dunia terlebih di masa pandemi saat ini, yang secara langsung akan berdampak pada ekonomi nasional tak terkecuali di tingkat regional Kabupaten Banyuwangi. Sehingga perlu adanya sebuah kajian tentang perbandingan kecepatan pembangunan dari setiap sektor ekonomisebagai landasan dalam pembangunan Kabupaten Banyuwangi. Menurut Sukirno (2011) pertumbuhan ekonomi merupakan suatu ukuran kuantitatif yang menggambarkan perkembangan suatu perekonomian dalam suatu tahun tertentu jika dibandingkan dengan tahun sebelumnya.

Berdasarkan pemaparan diatas, maka dalam penelitian ini akan dilakukan identifikasi sektor basis dan non basis lapangan usaha/industri yang dapat mengakselerasi sektor pariwisata dalam menumbuhkembangkan perekonomian di Kabupaten Banyuwangi. Identifikasi tersebut dilakukan dengan mengkombinasikan beberapa alat analisis yaitu analisis location quotient dan analisis shift share yang pada akhirnya dapat ditentukan sektor potensial di Kabupaten Banyuwangi. Adapun tujuan penelitian ini yaitu untuk mengetahui potensi sektor-sektor ekonomi serta keterkaitannya dengan industri pariwisata di Kabupaten Banyuwangi berdasarkan sektor basis dan non basis.

\section{Metodologi}

\subsection{Tahapan Penelitian}

Tahapan penelitian ini dimulai dengan pencarian data berupa data sekunder yaitu data yang didapatkan dari Badan Pusat Statistik. Data tersebut adalah data kontribusi terhadap Pendapatan Domestik Regional Bruto (PDRB) tahun 2015-2019 masing-masing sektor ekonomi berdasarkan lapangan usaha di Kabupaten Banyuwangi, data laju pertumbuhan ekonomi menurut harga konstan dan lain-lain. Data dipergunakan untuk mengidentifikasi sektor-sektor ekonomi di Kabupaten Banyuwangi. Selanjutnya data tersebut diolah dengan 2 analisis yaitu analisis location quotient dan analisis shift share. Berikut gambar tahapan penelitian ini. 


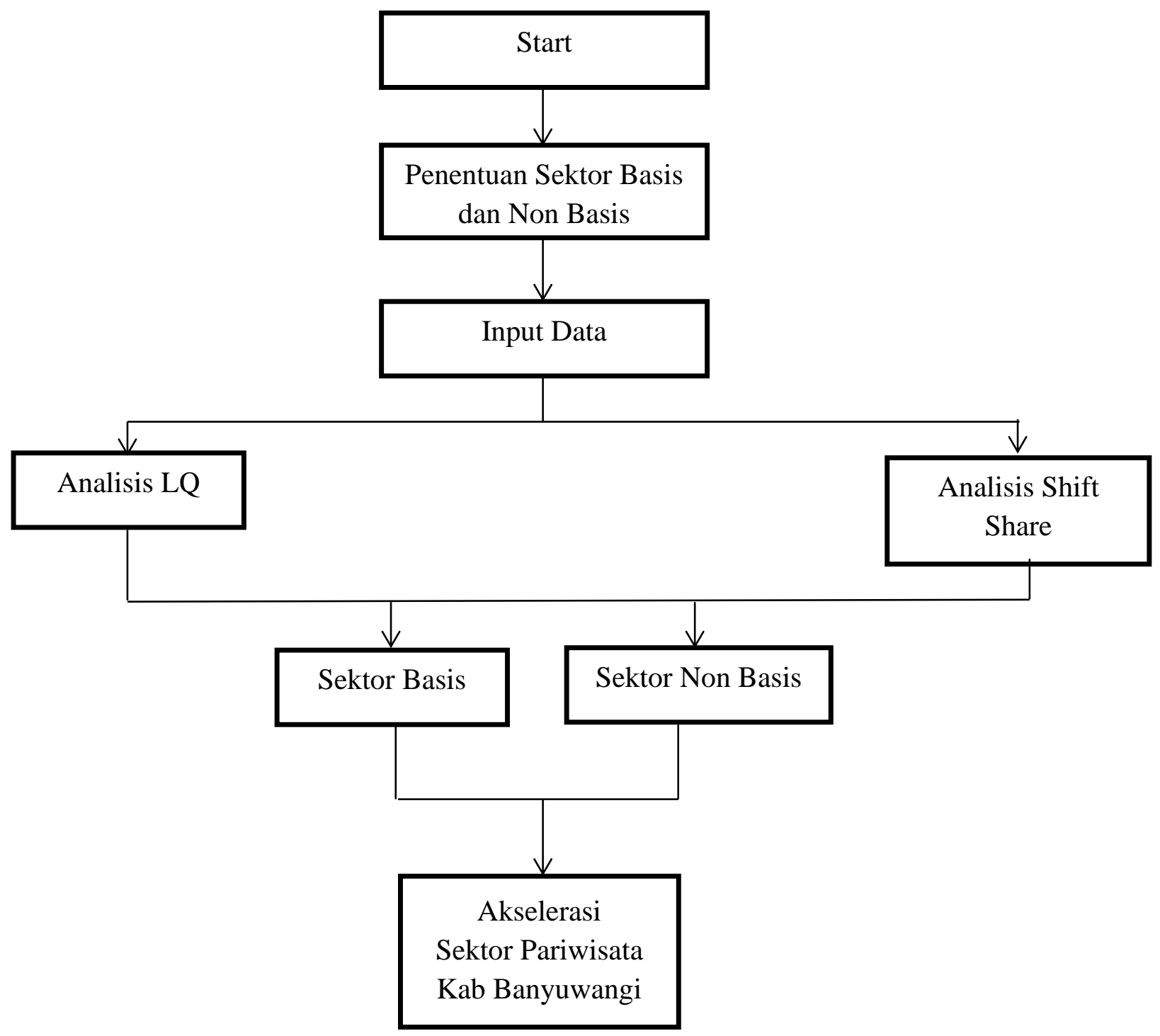

Gambar 1. Tahapan Penelitian

\subsection{Rancangan Penelitian}

Penelitian ini merupakan penelitian deskriptif serta metode yang digunakan dalam penelitian ini menggunakan metode kuantitatif. Penelitian ini menggunakan sumber data sekunder berupa angka bersumber dari Badan Pusat Statistik (BPS) Kabupaten Banyuwangi dan Provinsi Jawa Timur berupa data PDRB Atas Dasar Harga Konstan (ADHK) tahun 2010 selama tahun 2015 $-2019$.

Pada penelitian ini digunakan dua alat analisis yaitu analisis location quotient dan anlisis shift share. Analisis location quotient dipergunakan untuk mengukur keuntungan komparatif suatu sektor, subsektor atau komoditi (Sjafrizal, 2018). Selanjutnya analisis location quotient dapat digunakan untuk mengidentifikasi potensi dari aktivitas ekonomi yang merupakan indikasi dari sektor basis dan non basis (Rustiadi,2011).

$$
L Q i j=\frac{\mathrm{Xij} / \mathrm{Xi}}{\mathrm{Xj} / \mathrm{X}}
$$


Keterangan:

$\mathrm{LQ}_{\mathrm{ij}} \quad$ : indeks pemusatan aktivitas ke-j di wilayah ke-i

$\mathrm{X}_{\mathrm{ij}} \quad$ : derajat aktivitas ke-j di wilayah ke-i

$\mathrm{X}_{\mathrm{i}} \quad$ : total aktivitas di wilayah ke-i

$\mathrm{X}_{\mathrm{j}} \quad$ : total aktivitas ke-j di semua wilayah

$\mathrm{X} \quad$ : derajat aktivitas total wilayah

Suatu aktivitas j dinyatakan memusat di wilayah $\mathrm{I}$ jika $\mathrm{LQ}_{\mathrm{ij}}>1$

Analisis shift share membandingkan perbedaan laju pertumbuhan berbagai sektor (industri) didaerah dengan wilayah provinsi atau nasional. Analisis shift share memberikan penjelasan atas perubahan yang terjadi (Tarigan, 2018). Persamaan yang digunakan pada analisis shift share adalah sebagai berikut.

$$
\mathrm{SSA}=\left[\frac{X_{t 1}}{X_{t 0}}-1\right]+\left[\frac{X_{i(t 1)}}{X_{i(t 0)}}-\frac{X_{(t 1)}}{X_{(t 0)}}\right]+\left[\frac{X_{i j(t 1)}}{X_{j i(t 0)}}-\frac{X_{i(t 1)}}{X_{i(t 0)}}\right]
$$

Keterangan

$\mathrm{X} \quad$ : nilai total aktivitas dalam total wilayah

$\mathrm{X}_{\mathrm{i}} \quad$ : nilai total aktivitas tertentu dalam total wilayah

$\mathrm{X}_{\mathrm{ij}} \quad$ : nilai aktivitas tertentu dalam unit wilayah tertentu

$\mathrm{t}_{1} \quad$ : titik tahun akhir

$\mathrm{t}_{0} \quad$ : titik tahun awal

\section{Hasil dan Pembahasan}

Kabupaten Banyuwangi memiliki tujuh belas sektor lapangan usaha/industri yang berkontribusi mensuplai pendapatan daerah, seperti yang tertuang pada Banyuwangi dalam Angka. Sektor-sektor lapangan usaha/industri tersebut antara lain: (a) Industri pertanian, kehutanan dan perikanan; (b) Pertambangan dan penggalian; (c) Industri pengolahan; (d) Pengadaan listrik dan gas; (e) Pengadaan air, pengelolaan sampah, limbah dan daur ulang; (f) Konstruksi; (g) Perdagangan besar dan eceran, reparasi mobil dan sepeda motor; (h) Transportasi dan pergudangan; (i) Penyediaan akomodasi dan makan minum; (j) Informasi dan komunikasi; (k) Jasa keuangan dan asuransi; (l) Real estate; (m) Jasa perusahaan; (n) Administrasi pemerintahan, pertahanan dan jaminan sosial wajib; (o) Jasa pendidikan; (p) Jasa pendidikan; (q) Jasa kesehatan; (r) Jasa kesehatan dan kegiatan lainnya; dan (s) Jasa lainnya.

\subsection{Hasil Analisis Location Quotient (LQ)}

Berdasarkan hasil analisis Location Quotient (LQ) di Kabupaten Banyuwangi, ada beberapa sektor lapangan usaha/industri yang menjadi sektor basis yaitu sektor pertanian, kehutanan dan perikanan, pertambangan dan penggalian, konstruksi, jasa pendidikan, sementara selebihnya adalah sektor-sektor yang terkategori sebagai sektor non basis. Hal tersebut mengindikasikan bahwa sektor-sektor basis tersebut dapat menjadi poin utama dalam upaya mengakselerasi pariwisata dalam memacu pertumbuhan ekonomi di Kabupaten Banyuwangi. 


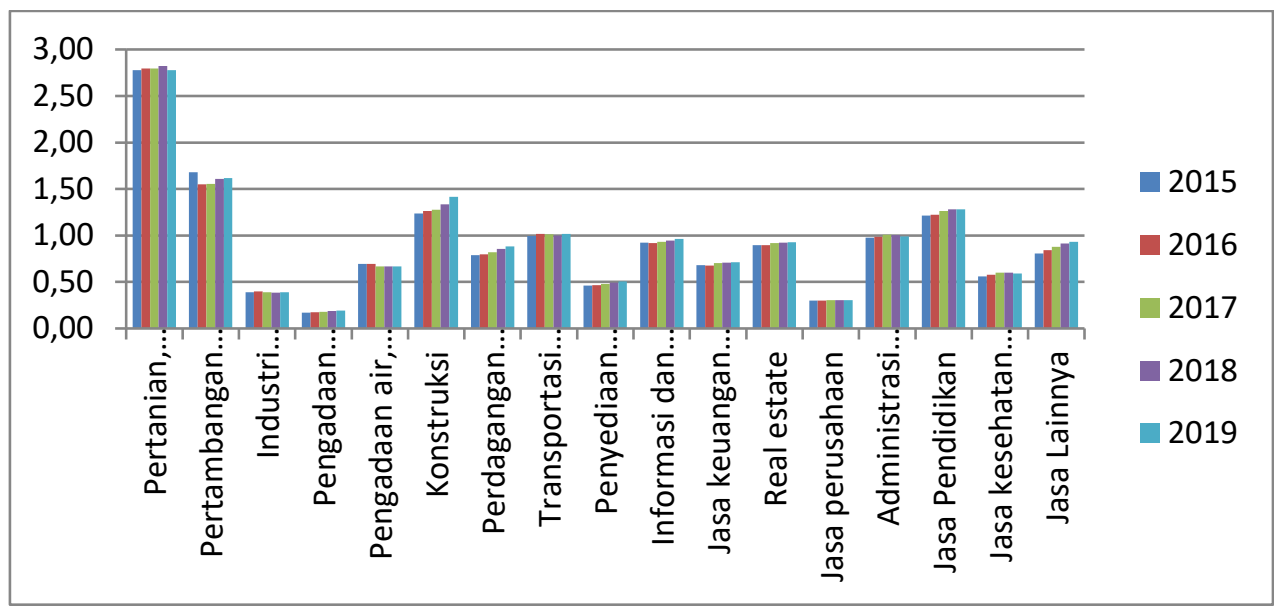

Gambar 2. Sektor Basis dan Non Basis Lapangan Usaha/Industri di Kabupaten Banyuwangi

Kolaborasi dan harmonisasi antara sektor basis dari lapangan usaha/industri tersebut dengan pariwisata akan menjadi peluang dalam mengembangkan perekonomian di Kabupaten Banyuwangi. Pariwisata memiliki keterkaitan ekonomi yang sangat erat dengan banyak sektor (Pitana, 2004). Seperti halnya kolaborasi sektor basis pertanian, kehutanan, dan perikanan dengan pariwisata (agrowisata dan ekowisata) dapat menjadi peluang pengembangan pariwisata agar dapat lebih berkontribusi dalam pengembangan ekonomi di Kabupaten Banyuwangi, misal melalui pembenahan destinasi wisata (agrowisata dan ekowisata).

Kolaborasi antara sektor basis lapangan usaha pertambangan dengan pariwisata dapat berbentuk regulasi dari Pemerintah Kabupaten Banyuwangi tentang konservasi lingkungan. Sehingga keberadaan sektor pertambangan memiliki pengaruh yang positif bagi konservasi lingkungan yang ada di Kabupaten Banyuwangi. Selanjutnya kolaborasi antara sektor basis lapangan usaha/industri yang ketiga yaitu usaha konstruksi yang dapat menjadi peluang dalam mengakselerasi sektor pariwisata melalui pembangunan fasilitas bagi wisatawan, seperti pembangunan akses jalan ke tempat wisata, hotel, dan fasilitas pendukung lainnya. Hal ini bersinergi dengan jumlah kunjungan wisatawan yang semakin meningkat di Kabupaten Banyuwangi. Berdasarkan data dari Dinas Kebudayaan dan Pariwisata Kabupaten Banyuwangi, jumlah kunjungan wisatawan domestik mencapai angka 5,31 juta dan jumlah wisatawan mancanegara mencapai angka 101,62 ribu pada tahun 2019. Harmonisasi antar sektor tersebut dapat mengakselerasi sektor pariwisata dalam perkembangan ekonomi di Kabupaten Banyuwangi.Sektor basis lapangan usaha/industri yang keempat yaitu jasa pendidikan. Adanya pengembangan usaha pendidikan dengan dibukanya sekolah kejuruan/vokasi pariwisata akan dapat mengakselerasi sektor pariwisata di Kabupaten Banyuwangi. Sehingga Kabupaten Banyuwangi dapat menghasilkan sumber daya manusia yang berkualitas bidang pariwisata.

Harmonisasi dari berbagai macam sektor ekonomi/lapangan usaha di Kabupaten Banyuwangi menjadikan pariwisata dapat berkembang menjadi lebih baik. Menurut Varesci dalam Yoeti (2008) menyatakan perencanaan pembangunan kepariwisataan berkelanjutan perlu dilakukan dengan pendekatan yang menyeluruh (comprehensive approach) sehingga tercipta hubungan yang serasi dengan semua sektor yang mendukung pariwisata sehingga pariwisata dapat tetap eksis. 


\subsection{Hasil Analisis Shift Share}

Kinerja masing-masing sektor lapangan usaha/industri dapat mengakselerasi pariwisata di Kabupaten Banyuwangi, terbukti dari hasil analisis shift share yang cenderung positif. Nilai Shift Share (Dij) di Kabupaten Banyuwangi yang ditunjukkan pada Tabel 1 dimana semua sektor lapangan usaha/industri memiliki nilai > 0, yang artinya terjadi kenaikan kinerja ekonomi pada masing-masing sektor di Kabupaten Banyuwangi. Hal ini mengindikasikan bahwa pertumbuhan ekonomi yang dialami oleh Kabupaten Banyuwangi merupakan outcome dari kenaikan kinerja pada sektor-sektor tersebut. Hal ini semakin memantapkan bahwa pariwisata di Kabupaten Banyuwangi dapat menjadi stimulus bagi sektor yang lain untuk tumbuh. Hal tersebut sangat relevan bahwa pariwisata merupakan sebuah fakta pembangunan (Nugroho, 2018). Selanjutnya menurut Rustiadi (2011) menyatakan bahwa suatu daerah akan mengalami percepatan pertumbuhan apabila memiliki sektor ekonomi yang mampu mengakselerasi pembangunan sektorsektor yang lain.

Tabel 1. Hasil Analisis Shift Share

\begin{tabular}{llr}
\hline & & \\
No & & Lapangan Usaha/Industri \\
& & \\
\hline 1 & Perdagangan besar dan eceran, reparasi mobil \& sepeda motor & 2706,97 \\
2 & Konstruksi & 2290,93 \\
3 & Industri Pengolahan & 1395,36 \\
4 & Informasi dan komunikasi & 856,72 \\
5 & Pertambangan dan penggalian & 848,28 \\
6 & Penyediaan akomodasi dan makan minum & 517,07 \\
7 & Jasa Pendidikan & 454,32 \\
8 & Pertanian, kehutanan dan perikanan & 448,30 \\
9 & Transportasi dan pergudangan & 359,65 \\
10 & Jasa Lainnya & 213,65 \\
11 & Jasa keuangan dan asuransi & 193,90 \\
12 & Real estate & 193,49 \\
13 & Administrasi pemerintahan, pertahanan dan jaminan sosial & 171,83 \\
14 & Wajib & 59,54 \\
15 & Jasa kesehatan dan kegiatan lainnya & 29,48 \\
16 & Pengadaan air, pengelolaan sampah, limbah dan daur ulang & 5,33 \\
17 & Pengadaan listrik dan gas & 4,09 \\
\hline & &
\end{tabular}

Nilai Diffential Shif (Cij) pada tabel 2, terdiri dari 15 sektor di Kabupaten Banyuwangi yang bernilai lebih besar dari 0, yang artinya bahwa mayoritas masing- masing sektor lapangan usaha di Kabupaten Banyuwangi memiliki daya saing yang lebih tinggi dibandingkan dengan sektor yang sama di Provinsi Jawa Timur. Sedangkan untuk nilai Diffential Shif (Cij) $<0$ hanya 2 sektor saja di Kabupaten Banyuwangi yaitu sektor pertambangan dan penggalian dengan sektor Pengadaan air, pengelolaan sampah, limbah dan daur ulang, yang artinya kedua sektor tersebut memiliki daya saing yang rendah jika dibandingkan dengan sektor yang sama di Provinsi Jawa Timur. Nilai Diffential Shif mencerminkan sektor dengan daya saing tinggi dibandingkan sektor referensi sehingga hal tersebut dapat disimpulkan bahwa sektor tersebut adalah sektor unggulan. Demikian dengan nilai Diffential Shif Kabupaten Banyuwangi secara keseluruhan adalah bahwa 15 sektor yang berdaya saing tinggi merupakan sektor unggulan di Kabupaten Banyuwangi yang layak untuk dikembangkan. Sektor-sektor tersebut merupakan sektor yang berkontribusi langsung ataupun tidak langsung dengan pariwisata. 
Tabel 2. Hasil Analisis Diffential Shif

\begin{tabular}{clr}
\hline & \multicolumn{1}{c}{ Lapangan Usaha/Industri } & Cij \\
\hline No & & \\
\hline 1 & Perdagangan besar dan eceran, reparasi mobil \& sepeda & \\
2 & motor & 998,95 \\
3 & Konstruksi & 926,85 \\
4 & Penyediaan akomodasi dan makan minum & 146,28 \\
5 & Jnformasi dan komunikasi & 134,62 \\
6 & Jasa Lainnya & 102,15 \\
7 & Jasa keuangan dan asuransi & 98,01 \\
8 & Transportasi dan pergudangan & 41,57 \\
9 & Real estate & 41,14 \\
10 & Administrasi pemerintahan, pertahanan dan jaminan & 33,30 \\
11 & sosial wajib & 16,87 \\
12 & Industri Pengolahan & 16,85 \\
13 & Jasa kesehatan dan kegiatan lainnya & 12,08 \\
14 & Pertanian, kehutanan dan perikanan & 4,25 \\
15 & Jasa perusahaan & 3,49 \\
16 & Pengadaan air, pengelolaan sampah, limbah dan daur & 1,66 \\
17 & ulang & $-1,39$ \\
& Pertambangan dan penggalian & $-166,08$ \\
\hline
\end{tabular}

Berdasarkan analisis diatas, pariwisata memiliki peran yang cukup besar bagi pembangunan perekonomian di Kabupaten Banyuwangi. Masyarakat dapat terlibat atau berperan secara langsung melalui program-program pengembangan pariwisata, sehingga pariwisata diharapkan dapat meningkatkan kesejahteraan rakyat di Kabupaten Banyuwangi. Pariwisata dalam hal ini diyakini sebagai katalisator dalam pembangunan (agent of development) dan sekaligus menjadi penggerak dan mempercepat proses pembangunan itu sendiri (Yoeti,2008).

\section{Kesimpulan}

Terdapat beberapa sektor lapangan usaha/industri yang dapat dikolaborasikan dalam mengakselerasi pariwisata di Kabupaten Banyuwangi antara lain, sektor basis di Kabupaten Banyuwangi yaitu sektor pertanian, kehutanan dan perikanan, sektor pertambangan dan penggalian, sektor konstruksi, sektor jasa pendidikan. Sementara untuk kinerja masing-masing sektor basis dari lapangan usaha/industri tersebut terhadap akselerasi pariwisata di Kabupaten Banyuwangi terbukti dari hasil analisis shift share yang cenderung positif.

\section{Saran}

Perlu adanya kajian lebih mendalam tentang hubungan masing-masing sektor ekonomi dengan sektor pariwisata dengan menggunakan pendekatan analisis input-output. 


\section{Ucapan Terimakasih}

Penelitian ini didanai oleh DIPA Politeknik Negeri Banyuwangi Tahun Anggaran 2020 dengan nomor kontrak : 2406.19/PL36/PT.01.03/2020 melalui Pusat Penelitian dan Pengabdian kepada Masyarakat Politeknik Negeri Banyuwangi, sehingga penelitian ini dapat dilaksanakan

\section{Daftar Pustaka}

Arianti, Desi. 2016. Pengaruh Sektor Pariwisata terhadap Perekonomian dan Keruangan Kota Bukittinggi (Pendekatan Analisis Input Output). Jurnal Pembangunan Wilayah dan Kota Vol.12 (4): 347-360

Badan Pusat Statistik Provinsi Jawa Timur. 2020. Produk Domestik Regional Bruto Provinsi Jawa Timur Menurut Lapangan Usaha 2015-2019. Surabaya. Badan Pusat Statistik Provinsi Jawa Timur.

Nugroho, Riant. 2018. Kebijakan Pariwisata. Yogyakarta:Pustaka Pelajar

Pitana, I Gde dan Putu G. Gayatri. 2004. Sosiologi Pariwisata. Yogyakarta: Penerbit Andi.

Rustiadi, E., Saefulhakim., \& Panuju, D.R.2011. Perencanaan dan Pengembangan Wilayah.Jakarta: Yayasan Pustaka Obor Indonesia.

Sjafrizal. 2018. Analisis Ekonomi Regional dan Penerapannya di Indonesia. Depok: Raja Grafindo Persada.

Sukirno, Sadono. 2011. Ekonomi Pembangunan: Proses, Masalah, dan Dasar Kebijakan. Jakarta: Kencana

Tarigan, Robinson. 2018. Ekonomi Regional Teori dan Aplikasi. Jakarta: Bumi Aksara.

Yoeti, Oka A. 2008. Perencanaan dan Pengembangan Pariwisata. Jakarta: PT Pradnya Paramita. Yoeti, Oka A. 2008. Ekonomi Pariwisata Intoduksi, Informasi, dan Aplikasi. Jakarta: Kompas. 